\title{
THE ROLE OF SELF-CONSTRUAL AND GOAL ORIENTATION ON EMPLOYEE INNOVATIVE WORK BEHAVIOR
}

\author{
Ernie Frislia, Seger Handoyo \\ Faculty of Psychology, Airlangga University \\ Jl. Airlangga 4-6, Kampus B Unair, Surabaya, Indonesia 60286 \\ ernie.frislia@gmail.com
}

\begin{abstract}
Innovation is an effort to increase the companies' competitiveness in Indonesia in the era of the ASEAN Economic Community and confront the fourth industrial era. Innovative work behavior is an organization's methods to implement innovations and improve performance, excellence, competitiveness, and confront changes in the dynamic external environment. This study aims to examine the effect of self-construal and goal orientation on innovative work behavior by testing hypotheses using multiple regression analysis. Data collection in this study uses an innovative work behavior scale, self-construal scale, and goal orientation scale, an online survey method filled by 168 employees working in the manufacturing industry sectors in Indonesia. The results show that selfconstrual and goal orientation have a positive effect on innovative work behavior, enhancement in self-construal, and goal orientation to increase employees' innovative work behavior - the contribution of goal orientation significant higher for employees' innovative work behavior than for self-construal contributions. Individuals with goal orientations can help organizations to develop innovation through innovative work behavior.
\end{abstract}

Keywords: self-construal; goal orientation; innovative work behavior

\begin{abstract}
Abstrak
Inovasi disebut sebagai upaya yang dapat mendongkrak daya saing perusahaan yang ada di Indonesia dalam era Masyarakat Ekonomi ASEAN dan menghadapi era industri keempat. Perilaku kerja karyawan adalah salah satu cara yang dapat digunakan organisasi dalam menerapkan inovasi untuk meningkatkan kinerja, keunggulan, daya saing, dan menghadapi perubahan lingkungan eksternal yang dinamis. Penelitian ini bertujuan untuk menguji peran dari self-construal dan goal orientation terhadap perilaku kerja inovatif dengan pengujian hipotesis menggunakan analisis regresi berganda. Pengambilan data pada penelitian ini menggunakan Skala Perilaku Kerja Inovatif, Skala Self-Construal, dan Skala Goal Orientation melalui survei daring yang diisi oleh 168 orang karyawan yang bekerja di perusahaan sektor industri manufaktur yang ada di Indonesia. Hasil penelitian ini mengindikasikan bahwa self-construal dan goal orientation berperan secara positif terhadap perilaku kerja inovatif, peningkatan self-construal dan goal orientation berdampak peningkatan perilaku kerja inovatif karyawan. Kontribusi goal orientation lebih besar terhadap perilaku kerja inovatif karyawan daripada kontribusi self-construal. Individu dengan goal orientation dapat membantu organisasi untuk mengembangkan inovasi melalui perilaku kerja inovatifnya.
\end{abstract}

Kata kunci: self-construal; goal orientation; perilaku kerja inovatif

\section{INTRODUCTION}

The low level of individual readiness for technology is the reason Indonesia falls behind in innovation, and this has led to the narrowing of innovative activities occurring in Indonesia (Schwab, 2017). A survey conducted by the International Labor Organization shows that companies in Indonesia encounter obstacles in increasing innovation caused by a lack of skilled labor
(International Labor Organization, 2017). Kleysen and Street (2001), in their research, found a relationship between innovation and the innovative work behavior of employees. Getz and Robinson (2003) found that in practice, $80 \%$ of ideas for improving company performance derived from employees, and only $20 \%$ of ideas emerge from improvement activities planned by the company.

The minister of industry argues that to increase the companies' competitiveness, 
Indonesia needs to strengthen innovation in the industrial sector (KEMENPERIN, 2017). Indonesia is in a period of "demographic bonus," which means that a productive age population is more than the young and the elderly. This situation becomes an opportunity, and all together challenges to provide the workforce with innovation power (KEMENAKER, 2016b). The minister of manpower added that employees need to initiate innovation in the business world to increase company productivity (KEMENAKER, 2016a). Madrid (2013) states that the main characteristics of innovation are the novelty of an idea, process, and product, the application of new ideas into the process or product, the potential benefits found from the novel idea and showing the results of the novel idea.

Several studies showed the importance of innovative work behavior for organizations, workgroups, and individuals. Many studies demonstrated that innovative work behavior in employees could help organizations achieve competitive advantage (Doner, 2012), it can be a significant source in increasing company competitiveness (Hana, 2013) and perform a function as a facilitator for the results of innovation strategies in product planning and development (Leong \& Rasli, 2014; Etikariena, 2018). More, Ornek and Ayas (2015) suggested that if innovative work behavior integrates with human resources, customer service, and organizational structure, which is intellectual capital, it will impact increasing organizational business performance. Li and Hsu (2016) suggest that innovative work behavior could solve customer service problems. In parallel, Dewi, Yuniasanti, and Prahara (2017) and Yulianti (2016) suggested that improving the quality of relationships within organizations is essential for innovative work behavior.

Furthermore, Doner (2012) consider the innovative work behavior in workgroups and suggested that innovative work behavior impacts the superiors' or managers' job effectiveness, belonging to individual workgroups. Doner (2012) and Afsar and Badir (2015) also support the importance of innovative work behavior for the individuals and declare their recommendation about the innovative work behavior through their research. They suggest that innovative work behavior can improve employee performance. The concept of innovative work behavior has developed rapidly, and many researchers examine everything related to innovative work behavior. West and Farr (in De Jong \& Den Hartog, 2010) suggest that innovative work behavior is deliberate individual behavior, which aims to achieve the initiation and introduction of new and useful ideas, processes, products, or procedures, which are usually shown in work, group roles, or organization. De Jong (2007) and Susrini, Muis, and Wahda (2019) suggest that innovative work behavior is individual behavior that leads to the initiation and introduction of new ideas, processes, products, or procedures and is useful in work, group or organizational roles. Logahan, Indrajaya, and Proborini (2014) suggest that innovative work behavior plays an essential role in increasing organizational effectiveness.

Several studies demonstrate that several factors influence individual behavior in making innovations in organizations, workgroups, and individuals. The factors existing in organizations encompass effortreward fairness and reward systems (Cingoz \& Akdogan, 2011; De Jong, 2007; Janssen, 2000; Zhou \& Velamuri, 2018), organizational culture, empowerment, organizational structure (Cingoz, \& Akdogan, 2011; Taghipour \& Dezfuli, 2013), organizational situational aspects (Soebardi, 2012), organizational memory and knowledge (Etikariena \& Muluk, 2014; Ong, Wan, \& Chng, 2003), intellectual capital (Ornek \& Ayas, 2015), and organizational-fit (Afsar \& Badir, 2015). Workgroup factors include leadership roles, leader-member exchange (Scott \& Bruce 1994; Scott \& Bruce, 1998), leader or managerial support (Basu \& Green, 1997; Cingoz \& Akdogan, 2011), 
consultation, delegation, and monitoring employee behavior conducted by participatory leaders (De Jong 2007; De Jong \& Den Hartog, 2010), good relations between employees and supervisors, open communication (Cingoz \& Akdogan, 2011; Yuan \& Woodman, 2010), supervisor behavior (Dorner, 2012), relational leadership, transformational, and transactional (Akram, Lei, \& Haider, 2016; Chatchawan, Trichandhara, \& Rinthaisong, 2017; Contreras, Espinosal, Dornberger, \& Acosta, 2017). Individual factors include work autonomy (Bysted, 2013; De Jong, 2007; Krause, 2004), job involvement (Tastan, 2013), job satisfaction (Bysted, 2013; Taghipour \& Dezfuli, 2013), job requirements, job characteristics (Cingoz \& Akdogan, 2011; De Jong, 2007; Yuan \& Woodman, 2010), individual emotional involvement, individual differences (Cingoz \& Akdogan, 2011; Contreras et al., 2017), and individual personalities such as proactive, self-efficacy, self-construal, and goal orientation (Afsar \& Badir, 2014; Alexander \& Knippenberg, 2014; De Jong, 2007; Gao, 2017; Qian, 2015; Tastan, 2013).

This study aims to correlate individual factors influencing employee innovative work behavior, including self-construal and goal orientation. Research on innovative work behavior indirectly influenced by the selfconstrual factor was conducted by Afsar and Badir (2014). They try to correlate transformational leadership with innovative work behavior with self-construal as one of the variables. The results show that the relationship between transformational leadership and innovative work behavior is more significant for employees with interdependent self-construals than employees with independent self-construals. This result refers to the theory that individuals with interdependent self-construals have (better) social relationships. Therefore, they persuade colleagues to support their ideas and apply the new idea easier than individuals with independent self-construals. Qian (2015) suggests that individuals with autonomy can actively implement innovations in the company. According to Markus and Kitayama (1991), individuals with autonomy are individuals with independent self-construals.

The concept of self-construal was first proposed by Markus and Kitayama (1991) to conceptualize cultural differences between individualism and collectivism at the individual level. Self-construal is a relationship between oneself and others and especially to what extent individuals notice themselves as a discrete portion from others or as a part connected with other people (Adriansyah, Aulia, Apriliyani, Puspita RC, \& Muhliansyah, 2018; Cherniece, Dwivedi, \& Slade, 2017; Singelis, 1994). Self-construal as a constellation of perceptions, feelings, and actions regarding the extent to which oneself is independent of others or interdependent with others (Bawono, 2016; Cross et al., 2011; Gavreliuc \& Ciobota, 2013; Khairunnisa, 2017; Markus \& Kitayama, 1991; Ramadhan \& Ardias, 2019; Greetings, 2018; Siswanto, 2018). Markus and Kitayama (1991) suggest that individuals with self-construals also have flexibility, social skills, and closeness to groups. These abilities affect individuals in proposing new ideas. Individuals with selfconstruals strive for new ideas by convincing colleagues and superiors. It enables coworkers and superiors to support the new idea to be applied in the work program. Fakhri (2017) argues that high self-construal plays a role in increasing self-control.

Markus and Kitayama (1991) differentiate self-construal into two dimensions: independent, self-construal, and interdependent. Behaviors characterize individuals with independent self-construal are formed based on thoughts, feelings, and actions from within themselves, not based on the thoughts, feelings, and actions of others around them. An important aspect of independent self-construal is the concept of self as an autonomous and independent person. Individuals with interdependent selfconstruals are individuals understanding themselves as part of social relationships. The 
uniqueness of the interdependent individual emerges from the developed type of relationships with others.

Consequently, when organizations need innovation, the independent or autonomous individuals will be open and readily explore their work environment, identify arising gaps or problems, and then propose or come up with ideas to solve them. Meanwhile, interdependent individuals tend to be more flexible in their behavior. Individuals can adapt to other people and are more adaptive to changing situations.

Furthermore, besides self-construal, goal orientation also indirectly influences the individual's innovative work behaviour. Research conducted by Alexander and Knippenberg (2014) suggests that innovation provides learning opportunities for individuals with goal orientation and willingness to accept a higher risk of failure in the innovation development process. Qian (2015) argues that once an organization introduces innovation, employees with different goal orientations will respond and evaluate innovation in different ways and face it in different ways. Klein et al. (In Qian, 2015) state that goal orientation is one of the critical factors in the process and implementation of innovation. Montani, Odoardi, \& Battistelli (2014) suggest that individuals with learning goal orientation can perceive planning positively and significantly related to innovative work behaviour. Goal orientation plays a vital role in increasing subjective well-being (Desiningrum, 2016) and happiness (Dini, 2019).

Dweck (in VandeWalle, 1997) was the first to introduce the concept of goal orientation. This concept explains that individuals with a goal orientation are individuals who are open to development and demonstrate the ability to achieve something. Brett and VandeWalle (1999) suggest that goal orientation is the concept of an individual's mental framework in interpreting and responding to an achievement. Goal orientation is a goal underlying behavior change (Dluha \& Solicha, 2018; Mariyanti, 2015; Nuraeni \& Yanuvianti, 2018). VandeWalle (1997) states that goal orientation consists of three dimensions: learning goal orientation, prove (performance) goal orientation, and avoid (performance) goal orientation. Learning goal orientation is the desire to develop self personally by acquiring new skills, mastering new situations, and increasing competence. Prove goal orientation is the desire to prove self-competence and to get a proper assessment of it. Avoid goal orientation is a desire to avoid denial of self-competence and to avoid negative judgments about it. Individuals with a goal orientation are individuals who are open to development and demonstrate their ability to achieve situations (VandeWalle, 1997). Thus, individuals will demonstrate their abilities in various ways to ensure that the individuals fully accomplished the final result of a job. In confronting challenges, individuals with a goal orientation will identify problems and then propose ideas to solve them. Afterward, if the individuals can figure out the problem using the idea, he will apply the idea to solve the existing problem. In an achievement, individuals will raise behavior correlating with innovative work behavior, showing the ability to achieve their ultimate work-goals.

Based on the previously described explanation, innovative work behavior is essential for the organization, workgroup, or individual in their occupation. Most of the research on innovative work behavior correlates with workgroup factors, which are related to leadership styles and colleagues' support toward individuals' innovation. Research on the relationship between individual factors and innovative work behavior has not been widely conducted. The study's limitation is a consideration for researchers to lead this research because individual factors play an important role in innovative work behavior. Previous studies have stated that self-construal and goal orientation are individual factors influencing innovative work behavior. Heretofore, there 
has been no research that directly examines the role of self-construal or goal orientation towards innovative employee work behavior. It is also essential to perform a more in-depth study of the role of self-construal and goal orientation towards innovative employee work behavior.

This study aimed to determine the role of selfconstrual and goal orientation towards the innovative work behavior of employees. The hypotheses of this study are:

1. self-construal plays a positive role in employee work innovative behavior;
2. goal orientation plays a positive role in employees' innovative work behavior; and

3. self-construal and goal orientation play a positive role in innovative employee work behaviour.

\section{METHOD}

The population in this study are employees working in the manufacturing industry sector. Table 1 shows the descriptions of the participants. The number of participants was 168 , with a mean age of 32.24 years and a standard deviation of 7.432 .

Table 1.

Socio-Demographic Characteristic

\begin{tabular}{cccc}
\hline $\begin{array}{c}\text { Socio-Demographic } \\
\text { Characteristic }\end{array}$ & Category & Quantity & $\begin{array}{c}\text { Percentage } \\
(\%)\end{array}$ \\
\hline \multirow{2}{*}{ Gender } & Male & 102 & 60.71 \\
& Female & 66 & 39.28 \\
Age & 19-30 years & 77 & 45.83 \\
& 31-40 years & 58 & 34.52 \\
& 41-56 years & 33 & 19.64 \\
& Senior/Vocational & 26 & 15.47 \\
Education Level & High School & & \\
& Diploma & 18 & 10.71 \\
& Bachelor & 120 & 71.42 \\
& Master & 4 & 2.38 \\
& Less than 1 year & 29 & 17.26 \\
Work Experience & 1-5 years & 60 & 35.71 \\
& 6-10 years & 57 & 33.92 \\
& $11-15$ years & 15 & 8.92 \\
& More than 15 years & 7 & 4.16 \\
Employee Status & Contract Employees & 45 & 26.78 \\
& Permanent Employees & 123 & 73.21 \\
\hline
\end{tabular}

This study uses a quantitative approach aiming to examine the role between selfconstrual and goal orientation towards innovative work behavior. The sampling method is a non-probability sampling technique, snowball sampling, conducted through online questionnaires filling. This study uses three scales: The Self-Construal Scale, the Goal Orientation Scale, and the Innovative Work Behavior Scale.

Researcher uses a self-construal scale from Singelis (1994). The self-construal scale consists of 24 items, which refer to the independent self-construal and interdependent self-construal dimensions. An example of a scale item is "I feel that my relationships with others are more important than my achievements." The reliability of this scale is .867 Cronbach's alpha. Seven response choices range from number 1 (strongly disagree) to number 7 (strongly agree), are provided on this scale. The higher the score obtained, the higher the level of self-construal is, and vice versa. 
This study used the goal orientation scale constructed by Vandewalle (1997) to measure goal orientation. The goal orientation scale consists of 13 items referring to the dimensions of learning goal orientation, prove goal orientation, and avoid goal orientation. An item example is "I enjoy to do the challenging and difficult assignments at work, where I will learn new skills." This scale provides six response choices ranging from 1 (strongly disagree) to 6 (strongly agree) and has a reliability of .807 Cronbach's alpha. The higher the score obtained, the higher the level of goal orientation they have, and vice versa.

The measurement of innovative work behavior uses an innovative work behavior scale constructed by De Jong (2007). The scale of innovative work behavior consists of 10 items referring to the dimensions of opportunity exploration, the emergence of ideas, the fight for ideas, and the application of ideas. An example item is "I submit innovative ideas systematically into my work practice." This scale provides five response options, ranging from 1 (never) to 6 (very often) and has a reliability of .920 Cronbach's alpha.

This study used multiple regression analysis with SPSS Statistic version 21 for Windows to analyze the data. Gudono (2015) and Ghozali (2016) suggest conducting several assumption tests before conducting multiple regression analyses. Researchers need to perform assumption tests to meet the regression model's underlying assumptions, including linearity test, homoscedasticity test, normality test, multicollinearity test, autocorrelation test, and correlation test. The result of the assumption tests met the criteria for multiple regression analyses.

\section{RESULTS AND DISCUSSION}

Table 2 shows the results of multiple analysis testing concerning the magnitude of selfconstrual and goal orientation (independent variable $\mathrm{X}$ ) role in innovative work behavior (dependent variable $\mathrm{Y}$ ).

Table 2.

Multiple Regression Analysis Model X to Y

\begin{tabular}{lcccc}
\hline Design & $b$ & $S E$ & $t$ & $p$ \\
\hline Self-construal towards innovative work behavior & .084 & .031 & 2.742 & .007 \\
Goal orientation towards innovative work behavior & .268 & .054 & 5.009 & .000 \\
\hline
\end{tabular}

Note. The effect is significant if the variable sig. value $<.05$.

Table 2 shows the role of self-construal on innovative work behavior with a significance value of $p=.007$. The results of this study are in line with Afsar and Badir (2014) research, which correlates the type of leadership with innovative work behavior by using selfconstrual as one of the variables. Research by Afsar and Badir (2014) shows a correlation between employees with self-construal and type of leadership with innovative work behavior. This study results reveal that individuals with self-construals can understand the organization's needs, leaders, and group members. Consequently, they can easily convince the group to understand and support their proposed idea. Individuals with self-construals can bring up individual innovative work behavior because of their flexible nature so that they can fight for their ideas by "selling" their ideas through seeking support from others.

The results of this study are in line with Qian's (2015) research, which suggests that autonomous individuals can actively implement innovations in the company. Individuals with self-construals are also independent and autonomous; therefore, when the organization support self-construals individuals, individuals with self-construals voluntarily propose their ideas of innovation and apply them in their work. The results of research by Imawati, Hadiansyah, Fadjrina, Marita, Gautama, and Ramadhani (2014) 
show that goal orientation has a significant effect on career development. Besides, research conducted by Gao (2017) states that autonomous individuals can benefit their knowledge better, apply it to solve the problems, and work efficiently. The autonomic characteristics suggested by Gao (2017) show a correlation with individuals' innovative work behavior in implementing innovation through the emergence of new ideas about new products, services or processes, improvements in current work processes, or make solutions for the identified problems.

Besides self-construal, Table 2 shows the role of goal orientation towards innovative work behavior with a significance value of $p<.001$. This study's results are in line with research conducted by Hirst, Knippenberg, \& Zhou (2009), which states that goal orientation reflects self-development beliefs and ways of directing individuals to interpret and engage with their environment. The result also correlates with one of the dimensions of innovative work behavior, namely, opportunity exploration. De Jong (2007) defines opportunity exploration as detecting a performance gap or incompatibility between potential and actual performance. Chatchawan et al. (2017) also stated that individuals with a goal orientation would be directly involved in organizational activities and development, especially in terms of innovation.

This study's results are also in line with the statement proposed by Alexander and Knippenberg (2014) that individuals with a goal orientation are willing to accept a higher risk of failure concerning innovation development. Innovative work behavior emerges as a form of response to a threat that requires improvement or aims to produce innovative outputs (De Jong, 2007). Sujarwo and Wahyono's (2017) research show that innovative behavior plays a role in improving employee performance.
The results of the self-construal regression analysis and goal orientation towards innovative work behavior show $F(2,165)=$ 27.304 with a significance value of .000 . This value is smaller than the standard of the significance of .05. This study's results support the previous studies, connecting selfconstrual and goal orientation with innovative work behavior. With the correlation of each of these independent variables, this study suggests the role of self-construal and goal orientation simultaneously towards innovative work behavior.

Individuals with Self-construal have flexible characteristics, have the closeness to groups, can work with others, are autonomous, have confidence in self-ability, have motivation for self-improvement (Gao, 2017; Markus \& Kitayama, 1991; Qian, 2015). These characteristics support the emergence of innovative work behaviors ranging from generating ideas, fighting for ideas by seeking peer support, to implementing ideas in organizations. Dowd and Artistico (2016) stated that independent individuals are associated with a more competitive figure because they tend to consider other people's abilities and compare them with their abilities.

Individuals with Goal orientation tend to be open to self-development, showing selfefficacy, and involvement in the organization (Hirst et al., 2009; VandeWalle, 1997). This characteristic supports innovative work behavior because individuals with openness to self-development are individuals with openness to organization development. Innovation could develop an organization. Innovative work behavior can be observed through achievement situations by demonstrating individuals' ability to maintain ideas and applying these ideas. Acarlar and Bilgic (2010) suggest that individuals with a learning goal orientation pursue difficult tasks to achieve their goals, namely adaptive response patterns. Puspitasari, Purwanto, \& Noviyani (2013) stated that goal orientation plays an essential role in self-regulated learning, and it leads to optimal efforts. 
This study's effect size is .240 , meaning that $24 \%$ of the variation in employee innovative work behavior can be explained by variations in self-construal variables and goal orientation, while other factors explain the remaining $76 \%$. Self-construal and goal orientation contribute to innovative work behavior by $24 \%$, and the rest is influenced by other factors not examined in this study.

The multiple regression equation line in this study is $\mathrm{Y}=14.045+.084 \mathrm{X} 1+.268 \mathrm{X} 2$. The constant value is 14.045 . The equation means that if the score of self-construal and goal orientation is 0 , the value of innovative work behavior is 14.045 in the constant. These results indicate that the study has reported the existence of innovative work behavior among employees. This equation shows that there will be an increase of .084 points in innovative work behavior for every one-point increase in self-construal. A one-point increase in the goal orientation will increase .268 points in innovative work behavior.

This study's limitation is the utilize of measuring instruments that have not been wholly adapted to the Indonesian culture. The instruments also lead to high social desirability. This study suggests future studies to use adapted measuring instruments. Adapted measuring instruments enable the study to precisely measure each item's meaning so that social desirability can be minimized.

\section{CONCLUSION}

Self-construal and goal orientation significantly contribute to innovative work behavior. Individuals with self-construal and goal orientation have the potential to generate innovative work behavior. This research implies that employees' innovative work behavior can be improved by paying attention to individual characteristics in terms of selfconstrual and goal orientation.

\section{REFERENCES}

Acarlar, G., \& Bilgic, R. (2010). A validation study of goal orientations and selfefficacy scales. Perceptual and Motor Skills, 111(3), 735-748. doi:10.2466/07.08.14.20.PMS. 111.6.735-748

Adriansyah, M. A., Aulia, M. R., Apriliyani, D., Puspita R. C., I. D., \& Muhliansyah. (2018). Self construal masyarakat daerah aliran sungai karang mumus dalam memprediksi sikap peduli lingkungan. Psikostudia: Jurnal Psikologi, 7(2), 1-11. doi:10.30872/psikostudia.v7i2.2401

Afsar B., \& Badir, Y. (2014). Transformational leadership and innovative work behavior. Industrial Management \& Data Systems, 114, 12701300. doi:10.1108/IMDS-05-2014-0152

Afsar, B., Badir, Y., \& Khan, M.M. (2015). Person-fit, person-organization fit and innovative work behavior: the mediating role of innovation trust. Journal of High Technology Management Research, 26, 105-116.

doi:10.1016/j.hitech.2015.09.001

Akram, T., Lei, S., \& Haider, M. J. (2016). The impact of relational leadership on employee innovative work behavior in IT industry of China. Arab Economic and Business Journal, 2, 153-161. doi:10.1016/j.aebj.2016.06.001

Alexander, L., \& Knippenberg, D.V. (2014). Teams in pursuit of radical innovation: A goal orientation perspective. Academy of Management Review, 39, 423-438. doi:10.5465/amr.2012.0044

Basu, R., \& Green, S.G. (1997). Leadermember exchange and transformational leadership: An empirical examination of innovative behaviors in leader-member dyads. Journal of Applied Social 
Psychology, 27, 477-499. doi:10.1111/j.1559-1816.1997.tb00643.x

Bawono, Y. (2016). Studi tentang self construal remaja etnis Madura dengan pendekatan indigeneous psychology. Jurnal Indigenous, 1(2), 20-32. doi:10.23917/indigenous.v1i1.3429

Brett, J.F., \& VandeWalle, D. (1999). Goal orientation and goal content as predictors of performance in training program. Journal of Applied Psychology, 84, 863873. doi:10.1037/0021-9010.84.6.863

Bysted, R. (2013). Innovative employee behaviour the moderating effects of mental involvement and job satisfaction on contextual variables. European Journal of Innovation Management, 16, 268-284. doi:10.1108/EJIM-09-20110069

Chatchawan, R., Trichandhara, K., \& Rinthaisong, I. (2017). Factors affecting innovative work behavior of employees in local administrative organizations in south of Thailand. International Journal of Social Sciences and Management, 4, 154157. doi:10.3126/ijssm.v4i3.17755

Cherniece, J.P., Dwivedi, Y.K., \& Slade, E.L. (2017). Social media in the marketing context. A state of the art analysis and future directions. United states: Chandos Publishing

Cingoz, A., \& Akdogan, A. A. (2011). An empirical examination of performance and image outcome expectation as determinants of innovative behavior in workplace. Social and Behavioral Sciences, $\quad 24, \quad 847-853$. doi:10.1016/j.sbspro.2011.09.099

Contreras, F., Espinosal, J. C., Dornberger, U., \& Acosta, Y. A. C. (2017). Leadership and employees innovative work behavior: Test of mediation and moderation model.
Asian Social Science, 13, 9-24. doi:10.5539/ass.v13n9p9

Cross, S.E., Hardin, E.E., \& Gercek-Swing, B. (2011). The what, how, why, and where of self-construal. Personality and Social Psychology Review, 15(2), 142-179. doi:10.1177/1088868310373752

De Jong, J. P. J. (2007). Individual innovation: The connection between leadership and employees innovative work behavior (Doctoral Dissertation). Retrieved from https://hdl.handle.net/11245/1.294007

De Jong, J. P. J., \& Den Hartog, D. N. (2007). How leaders influence employees' innovative work behaviour. European Journal of Innovation Management, 10, 41-64. doi:10.1108/14601060710720546

De Jong, J., \& Den Hartog, D. (2010). Measuring innovative work behavior. Creativity and Innovation Management, 19 , 23-36. doi:10.1111/j.14678691.2010.00547.x

Dewi, L. F. A. A., Yuniasanti, R., \& Prahara, S. A. (2017). Hubungan persepsi terhadap lingkungan kerja dengan perilaku inovatif karyawan bagian penjualan. Insight: Jurnal Ilmiah Psikologi, 19(1), 13-25. doi:10.26486/psikologi.v19i1.597

Desiningrum, D. R. (2016). Goal orientation dan subjective well being pada lansia. Jurnal psikologi, 15(1), 43-55. doi:10.14710/jpu.15.1.43-55

Dini, S. G. (2019). Hubungan goal orientation dan kebahagiaan pada mahasiswa baru jurusan psikologi Universitas Negeri Yogyakarta. Jurnal Mahasiswa Psikologi, 1(4), 1-11. doi:10.21831/ap.v1i4.16275

Dluha, M. S., \& Solicha. (2018). Pengaruh perfeksionisme, achievement goal orientation dan jenis kelamin terhadap prokrastinasi akademik mahasiswa. 
Tazkiya Journal of Psychology, 6(1), 5368. doi:10.15408/tazkiya.v6i1.11003

Dorner, N. (2012). Innovative work behavior: The roles of employee expectations and effect on job performance (Doctoral Dissertation). Retrieved from https://www1.unisg.ch/www/edis.nsf/Sys LkpByIdentifier/4007/\$FILE/dis4007.pdf

Dowd, S.M., \& Artistico, D. (2016). Type and strength of self-construal interact with the influence of anchoring heuristic in appraisals of self-efficacy. Learning and Individual Differences, 49, 400-405. doi:10.1016/j.lindif.2016.05.018

Etikariena, A. (2018). Perbedaan perilaku kerja inovatif berdasarkan karakteristik individu karyawan. Jurnal Psikologi, $17(2)$, 107-118. doi:10.14710/jp.17.2.107-118

Etikariena, A., \& Muluk, H. (2014).

Hubungan antara memori organisasi dan perilaku inovatif karyawan. Makara Hubs-Asia, 18, 77-88. doi:10.7454/mssh.v18i2.3463

Fakhri, N. (2017). Perbedaan tingkat berpikir construal terhadap kontrol diri pada mahasiswa. Jurnal Psikologi Pendidikan \& Konseling, 3(2), 37-40. doi:10.26858/jpkk.v0i0.3018

Gao, M. (2017). A self-determination approach to understanding employees' innovative work behavior (Master's Thesis). Retrieved from https://spectrum.library.concordia.ca/982 $317 /$

Gavreliuc, A., \& Ciobota, C. I. (2013). Culture and self-construal: implications for the social cognitions of young cohorts in Romania. Procedia - Social and Behavioral Sciences, 78, 270-274. doi:10.1016/j.sbspro.2013.04.293
Getz, I., \& Robinson, A. G. (2003). Innovate or die: Is that a fact? Creativity and Management, $12, \quad 130-136$. doi:10.1111/1467-8691.00276

Ghozali, I. (2016). Aplikasi analisis multivariate dengan program IBM SPSS 23. Semarang: Badan Penerbit Universitas Diponegoro.

Gudono, (2015). Analisis data multivariat (edisi keempat). Yogyakarta: BPFEYogyakarta.

Hana, U. (2013). Competitive advantage achievement through innovation and knowledge. Journal of Competitiveness, 5, 82-96. doi:10.7441/joc.2013.01.06

Hirst, G., Knippenberg, V.D., \& Zhou, J. (2009). A cross-level perspective on employee creativity: goal orientation, team learning behavior, and individual creativity. Academy of Management Journal, 52, 280-293.

Imawati, R., Hadiansyah, A., Fadjrina, A., Marita, D., Gautama, I. H., \& Ramadhani, M. W. (2014). Hubungan self efficacy dan goal orientation terhadap career development pada para pencari kerja PT. Bina Talenta. Jurnal Al-Azhar Indonesia Seri Humaniora, 2(3), 177-188. doi:10.36722/sh.v2i3.144

International Labour Organization (2017). Laporan ketenagakerjaan Indonesia 2017: Memanfaatkan teknologi untuk pertumbuhan dan penciptaan lapangan kerja. Jakarta: International Labour Organization. Retrieved from International Labour Organization website:

https://www.ilo.org/wcmsp5/groups/publi c/---asia/---ro-bangkok/---ilojakarta/documents/publication/wcms_613 626.pdf

Janssen, O. (2000). Job demands, perceptions of effort-reward fairness and innovative 
work behavior. Journal of Occupational and Organizational Psychology, 73, 287302. doi:10.1348/096317900167038

Kementerian Ketenagakerjaan Republik Indonesia. (2016a, Maret 22). Angkatan kerja muda harus tingkatkan daya saing di pasar kerja. Diakses dari https://www.beritasatu.com/ekonomi/356 255-angkatan-kerja-muda-harustingkatkan-daya-saing-di-pasar-kerja

Kementerian Ketenagakerjaan Republik Indonesia. (2016b, April 26). Menaker minta serikat buruh pelopori inovasi. Diakses dari https://lamongankab.go.id/disnaker/?p=8 157

Kementerian Perindustrian Republik Indonesia. (2017, September 30). Daya saing Indonesia naik, produk industri semakin kompetitif. Diakses dari http://www.kemenperin.go.id/artikel/ 18210/Daya-Saing-Indonesia-Naik,Produk-Industri-Semakin-Kompetitif

Khairunnisa. (2017). Pengaruh self construal terhadap komitmen organisasi dosen. Jurnal Sekretari, 4(1), 1-13. doi:10.32493/skr.v4i1.607

Kleysen, R. F., \& Street, C. T. (2001). Toward a multi-dimensional measure of individual innovative behavior. Journal of Intellectual Capital, 2, 284-296. doi:10.1108/EUM0000000005660

Krause, D. E. (2004). Influence-based leadership as a determinant of the inclination to innovate and of innovationrelated behaviors an empirical investigation. The Leadership Quarterly, 15 , 79-102. doi:10.1016/j.leaqua.2003.12.006

Leong, C. T., \& Rasli, A. (2014). The relationship between innovative work behavior on work role performance: An empirical study. Social and Behavioral
Sciences, 129 , 592-600. doi:10.1016/j.sbspro.2014.03.717

Li, M., \& Hsu, C. H. C. (2016). Linking customer-employee exchange and employee innovative. International Journal of Hospitality Management, 56, 87-97. doi:10.1016/j.ijhm.2016.04.015

Logahan, J. M., Indrajaya, A., \& Proborini, A. W. (2014). analisis pengaruh perilaku inovatif dan self-esteem terhadap organizational citizenship behavior di PT. Stannia Binekajasa. Binus Business Review, 5(1), 396-403. doi:10.21512/bbr.v5i1.1261

Madrid, H. P. C. (2013). On innovation as an affect-driven work behaviour (Doctoral Dissertation). Retrieved from http://etheses.whiterose.ac.uk/4528/

Mariyanti, S. (2015). Model goal orientation sebagai efek dari persepsi quality of school life serta implikasinya terhadap prestasi mahasiswa psikologi. Jurnal Psikologi, 13(2), 57-64, https://ejurnal.esaunggul.ac.id/index.php/ psiko/article/view/1426

Markus, H. R., \& Kitayama, S. (1991). Culture and the self: Implications for cognition, emotion, and motivation. Psychological Review, 98, 224-253. doi:10.1037/0033-295X.98.2.224

Montani, F., Odoardi, C., \& Battistelli, A. (2014). Individual and contextual determinants of innovative work behavior: Proactive goal generation matters. Journal of occupational and organizational psychology, 87, 645-670. doi:10.1111/joop.12066

Nuraeni, I., \& Yanuvianti, M. (2018). Hubungan goal orientation dengan student engagement pada siswa kelas 8A di SMPN 3 Baleendah. Prosiding Psikologi, $4(1)$,

262-267. 
http://karyailmiah.unisba.ac.id/index.php/ psikologi/article/view/9470

Ong, C. H., Wan, D., \& Chng, S.H. (2003). Factors affecting individual innovation: An examination within a Japanese subsidiary in Singapore. Technovation, 23, 617-631. doi:10.1016/S01664972(02)00019-6

Ornek, A. S., \& Ayas, S. (2015). The relationship between intellectual capital, innovative work behavior and business performance reflection. Social and Behavioral Sciences, 195, 1387-1395. doi:10.1016/j.sbspro.2015.06.433

Puspitasari, A., Purwanto, E., \& Noviyani, D. I. (2013). Self regulated learning ditinjau dari goal orientation. Educational Psychology Journal, 2(1), 1-6. https://journal.unnes.ac.id/sju/index.php/e pj/article/view/2579

Qian, X. (2015). Goal orientation and innovation implementation forms (Master's Thesis). Retrieved from http://sspace.snu.ac.kr/handle/10371/124608

Ramadhan, R. F., \& Ardias, W. S. (2019). Konstrual diri (self construal) remaja yang mengalami kematian orang tua. Jurnal Psikologi Islam Al-Qalb, 10(1), 79-90. doi:10.15548/alqalb.v10i1.831

Salam, G. N. (2018). Pengaruh gender dan construal of self terhadap keputusan auditor dalam menghadapi konflik audit. Jurnal Akuntansi, 6(1), 1-17, http://ejournal.unp.ac.id/students/index.p hp/akt/article/view/2769

Schwab, K. (2017). Insight report, the global competitiveness report 2017-2018. Geneva: World Economic Forum Retrieved from World Economic Forum website: http://www3.weforum.org/docs/GCR201 7-
2018/05FullReport/TheGlobalCompetitiv enessReport2017\%E2\%80\%932018.pdf

Scott, S. G., \& Bruce, R. A. (1994). Determinants of innovative behavior: A path model of individual innovation in the workplace. Academy of Management Journal, $\quad 37, \quad 580-607$. doi:10.2307/256701

Scott, S.G., \& Bruce, R. A. (1998). Following the leader in R\&D: The joint effect of subordinate problem-solving style and leader-member relations on innovative behavior. IEEE Transactions on Engineering Management, 45, 3-10. doi:10.1109/17.658656

Singelis, T. M. (1994). The measurement of independent and interdependent selfconstrual. Personality and Social Psychology Bulletin, 20, 580-591. doi:10.1177\%2F0146167294205014

Siswanto, Y. (2018). In-group favoritsm pada mahasiswa aktivis ditinjau dari konstrual diri independen-interdependen. Jurnal Ilmiah Psikologi Terapan, 2(1), 184-198. doi:10.22219/jipt.v2i1.1779

Soebardi, R. (2012). Perilaku inovatif. Jurnal Psikologi Ulayat, 1, 57-74. doi:10.24854/jpu12012-10

Sujarwo, A., \& Wahjono. (2017). Pengaruh motivasi kerja dan perilaku inovatif terhadap kinerja karyawan dengan kepuasan kerja sebagai variabel mediasi (Studi kasus pada LKP Alfabank Semarang). Jurnal Amik JTC Infokam, 13(1), 63-71. https://amikjtc.com/jurnal/index.php/jurn al/article/view/121

Susrini, R., Muis, M., \& Wahda. (2019). Pengaruh iklim organisasi dalam mendorong perilaku inovatif melalui kreativitas (studi kasus pada PT. Telkom (persero) tbk. witel Makassar). Hasanuddin Journal of Applied Business 
and Entrepreneurship, 2(1), 95-105. doi:10.26487/hjabe.v2i1.144

Tastan, S. B. (2013). The influence of participative organizational climate and self-leadership on innovative behavior and the roles of the job involvement and proactive personality: A survey in context of SMEs in Zimir. Procedia - Social and Behavioral Sciences, 75, 407-419. doi:10.1016/j.sbspro.2013.04.045

Taghipour, A., \& Dezfuli, Z. K. (2013). Innovative behaviors: Mediate mechanism of job attitudes. Social and Behavioral Sciences, 84, 1617-1621. doi:10.1016/j.sbspro.2013.07.001

VandeWalle, D. (1997). Development and validation of a work domain goal orientation instrument. Educational and Psychological Measurement, 57, 995-
1015.

doi:10.1177\%2F0013164497057006009

Yuan, F., \& Woodman, R.W. (2010). Innovative behavior in the workplace: The role of performance and image outcome expectations. Academy of Management Journal, 53 , 323-342. doi:10.5465/AMJ.2010.49388995

Yulianti, P. (2016). Membangun perilaku inovatif dosen perguruan tinggi. Jurnal Studi Manajemen dan Bisnis, 3(1), 31-39. doi:10.21107/jsmb.v3i1.2566

Zhou, W., \& Velamuri, V. K. (2018). Key contextual success factors for employee innovative behavior: A study in foreign manufacturing subsidiary in China. Cogent Business and Management, 5, 118. doi:10.1080/23311975.2018.1471770 